\section{Reprieve for academy}

\section{Munlch}

THE East German Academy of Sciences is to be given an extra year to complete the massive process of restructuring required for it to be integrated into the West German scientific system. The academy, by far the largest research organization in East Germany, will now be given until the end of 1991 to finish its reforms, by which time a scientific review carried out by the West German science advisory council, Wissenschaftsrat, will be complete.

The West German Research Ministry (BMFT) agreed to the reprieve after the Länder and West German science organizations rejected Research Minister Heinz Riesenhuber's proposal to hack the academy down to size by the end of this year on the basis of only a rough evaluation by the Wissenschaftsrat (see Nature 346, 8; 5 July 1990).

In a strongly worded letter, Science Minister Marianne Tidick of SchleswigHolstein argued that a quick change would be unfair to researchers and to the yet-to-be-created Länder in East Germany. By granting BMFT nearly dictatorial powers over East German research, the Länder felt an uncomfortable precedent would be set for West German COMPUTERS

\section{Hacker's genius award \\ Boston}

RICHARD Stallman, a programmer who, at the age of 37 , is well known as a colourful and strident advocate of free, public access to computer software, is among this year's recipients of the John D. and Catherine T. MacArthur foundation's 'genius' fellowships which are awarded annually to a disparate group of artists, writers, scientists and political activists. This year's awards have yet to be formally announced but Stallman, whose selection is sure to annoy the corporate heads of many large commercial software companies, acknowledged publicly his receipt of the $\$ 240,000$, five-year fellowship early this week.

In August, Stallman says he plans to lead a public demonstration against one such company, Lotus, Inc., based in Cambridge, Massachusetts to protest at a new lawsuit the company has brought against a competitor. The MacArthur award, he says, will help him step up his battle against what he calls "the new monopoly" on computer software, and allow him to support others working on "free software". Stallman, whose waist-length hair and beard fit closely his unorthodox, 'hacker' image, severed all formal contacts with Massachusetts Institute of Technology (MIT) in 1984 to ensure there could never be a claim of MIT ownership of any part of his work.

Seth Shulman science policy.

In advance of its full evaluation, Wissenschaftsrat estimated last week that refurbishing East German universities and research institutes would cost a minimum of DM6,500 million $(\$ 4,000$ million) over five years. This amount is more than the entire budget of West Germany's Max Planck Society.

The East German Research Ministry estimates that it can cover just 20 per cent of the research costs but all the personnel costs of the academy for the remainder of 1990. The ministry implies that it may find more funds by using money originally earmarked for investment. How the new East German Länder, especially Berlin, will finance their universities is still a mystery. If Berlin is recreated as a single Land, as is currently planned, it will have three major universities.

Reports that the East Germany Academy would fire 14,000 of its 24,000 employees before the end of the year have turned out to be deliberate falsehoods reminiscent of Communist disinformation of years past - released to the public in order to provoke a response from academy employees. The alleged cuts were leaked to the press and then dictated to institute directors at a meeting in East Berlin on 25 June. The strategy succeeded. Thousands of demonstrators gathered outside the meeting at the Adlershof research campus to protest against the threat to their jobs.

But just a day later, the Research Ministry denied that mass dismissals were planned. Only 3,000 to 5,000 people will be removed from the academy through early retirement or when institutes are turned into private companies.

Benno Parthier, director of an academy institute in Halle and the new president of the Akademie Leopoldina, said he expected the real number of layoffs to fall between the two estimates.

Wilhelm Krull of Wissenschaftsrat said he expects to receive a variety of recommendations on where to resettle academy researchers and institutes. There are many more options, he said, than just dissolving institutes, recreating them as Max Planck or Fraunhofer institutes (for basic and applied research respectively) or resettling them at universities. Some institutes might, for example, be turned into dedicated institutes in specific fields by the new Länder.

Bringing research back to universities in East Germany, from which it was forcibly removed 40 years ago, will be a long and arduous task, said Krull. At first, only isolated research groups will probably be moved, not least because research costs money and the new Länder will not be able to pay for it.

Steven Dickman
A plan for spending money

\section{Sydney}

IN a new report that may serve as a base for a reworking of the way universities are financed, the Australian federal government divides academic disciplines into five classes according to their teaching cost per student. Universities that are overfunded, according to the definitions, will be expected to take more students for the same total amount of money, and those that are underfunded will be allowed to shed students or will receive more government money.

The report, prepared by a joint committee of the Commonwealth Department of Employment, Education and Training and the Higher Education Council, puts accounting and the law among the cheapest undergraduate courses to teach and, as expected, finds agriculture, dentistry, medicine and veterinary science the most expensive, costing 2.95 times as much per student as the courses in the first category. Science and engineering occupy the fourth group, with 2.20 times the cost of the first.

The Federation of Australian University Staff Associations has strongly criticized the report. According to the general secretary, Di Zetlin, "calculations for this report have been based on only three teaching cost studies, all with small sample sizes and all coming up with different results". Zetlin claims that the report discriminates against "low cost/high infrastructure" disciplines such as those in the

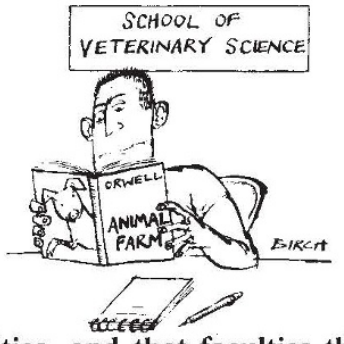

humanities, and that faculties that cover areas in the high cost category will "do very well indeed at the expense of law, accounting and mathematics".

A separate report, issued recently by a Senate standing committee, criticizes the practice of employing university teachers on the basis of their published work rather than their educational abilities, with the result that Australian universities and higher-education colleges are turning out "skilled barbarians." The report, "Priorities for Reform in Higher Education," found that $\mathbf{4 0}$ per cent of graduates proceeding to a diploma in education failed simple literacy tests; science and medical graduates were "culturally illiterate," completing their courses without having written a substantial piece of English; and fewer than one in three humanities students could summarise a passage of prose by George Orwell. Tania Ewing 